Evija Vīnkalna, $M g . s o c$.

Latvijas Universitātes Juridiskā fakultāte, Latvija

\title{
CĒLON̦SAKARĪBAS IZPRATNE, ATTĪSTĪBAS TENDENCES UN NOZĪME KRIMINĀLTIESĪBĀS
}

\section{UNDERSTANDING CAUSAL RELATIONSHIP, ITS DEVELOPMENT TENDENCIES AND SIGNIFICANCE IN CRIMINAL LAW}

\begin{abstract}
Summary
Causal relationship is one of necessary prerequisites for criminal liability in material corpus delicti. Causation theories have the key role to play in determining causal relationship. Propounding of these theories reasonably draws an increasing attention within Latvian criminal law, acknowledging their importance in practice. The article highlights the importance of causation type, such as alternative causation, during criminal offence's qualification and the assessment of causation types in the theory of criminal law.
\end{abstract}

Atslēgvārdi: cēloṇsakarība, Krimināllikums, krimināltiesības, noziedzīgs nodarījums

Keywords: causal relationship, the Criminal Law, criminal law, criminal offence

\section{Ievads}

Cēlon,sakarība ir materiālo noziedzīgu nodarījumu sastāvu objektīvās puses pazìme, kas nozīmē, ka materiālo noziedzīgo nodarījumu kvalifikācija nav iespējama bez cēlon,sakarības konstatēšanas. Cenšoties rast precīzu cēloṇsakarības raksturojumu un vienveidību tās noteikšanā, krimināltiesībās izstrādātas cēloṇsakarības teorijas, kuru nostādnes plašāku izvērtējumu gūst arī Latvijas krimināltiesībās. Raksta mērḳis ir akcentēt cēloṇsakarības teoriju ietekmi cēlon,sakarības izpratnes veidošanā un to nozīmi praksē.

Cēloņsakarība (nexus causalis) pamatoti uzskatāma par vienu no nozīmīgākajiem jautājumiem krimināltiesībās, ${ }^{1}$ n,emot vērā, ka materiālo noziedzīgo nodarījumu kvalifikācija pēc objektīvās puses nav iespējama bez cēloṇsakarības konstatēšanas. ${ }^{2}$

1 Sk., piem., Козаченко И. Я., Курченко В. Н., ЗАоченко Я. М. Пробцемы причины и причинной связи в институтах Общей и Особенной частей отечественного уголовного права: вопросы теории оперативно-слеАственной и судебной практики. Санкт-Петербург: ЮриАический центр Пресc, 2003; Langsted L. B., Greve V. Criminal Law. Denmark. 2. ed. Copenhagen: DJOF Publishing, 2004.

2 Liholaja V. Noziedzīgu nodarījumu kvalifikācija: Likums. Teorija. Prakse. Otrais papildinātais izdevums. Rìga: Tiesu nama aǵentūra, 2007, 40., 41. lpp.

Cēloṇsakarība Latvijas krimināltiesībās pamatoti nostiprināta kā materiālo noziedzīgo nodarījumu sastāvu pazīme, taču atsevišķa pētījuma vērts ir jautājums, vai cēloṇsakarības noteikšana aprobežojas tikai ar materiālo noziedzīgo nodarījumu sastāviem. Atsevišķos gadījumos cēloṇsakarību varētu izvērtēt 
Cēloṇsakarībai Latvijas krimināltiesībās pievērsta uzmanība gan dažādu autoru darbos, to skaitā arī izvērstos pētījumos, ${ }^{3}$ gan tās noteikšanas problemātika vērtēta praksēe. ${ }^{4}$ Tā, piemēram, profesors Pauls Mincs, uzsvērdams cēloṇsakarības būtisko nozīmi, norādījis, ka "pieskaitīt nodarijumu par vainu nav iespējams, nenostādot noziedzīgu rezultātu sakarā ar cilvēka ārējo uzvešanos. Ciktāl šo sakaru redz cilvēka aktivitātē, no kuras cēlies zināms ārējs rezultāts, pieṇemts runāt par cēlonisko sakaru [..]". ${ }^{5}$ Atzīstot cēloṇsakarības būtisko nozīmi, jāakcentē, ka tās izvērtēšana un problemātiskie jautājumi uzsvērti ne tikai krimināltiesībās. ${ }^{6}$ Lai gan cēlonssakarības izpratne arī dažādās tiesību apakšnozarēs var atšksirties, tā var būt viens no atbildības priekšnoteikumiem krimināltiesībās, civiltiesībās, administratīvajās tiesībās. ${ }^{7}$ Cēloṇsakarỉbas definējumu nav raksturīgi ietvert krimināllikumā. Līdzīgi kā lielākajā dạ̄āārvalstu, ne krimināllikumos, kas bijuši spēkā Latvijas teritorijā, ${ }^{8}$ ne Krimināllikumā̄ cēlon,sakarības izpratne nav skaidrota. ${ }^{10}$ Tomēr cēloṇsakarība kā noziedzīga nodarijuma sastāva pazīme izriet no normas uzbūves, tās konstatēšanas nepieciešamību nosakot ar noziedzīga nodarījuma sastāvā ietvertajām kaitīgajām sekām. Krimināltiesību normās cēloṇsakarības apzīmēšanai lietoti arī dažādi termini ${ }^{11}$ - "izraisît" (Krimināllikuma 138. panta pirmā dal̦a), "radīts" (Krimināllikuma 319. panta pirmā dal̦a), "nodarīts" (Krimināllikuma 260. panta pirmā daļa), "bijis par iemeslu” (Krimināllikuma 125. panta trešā daļa). Cēloṇsakarības definīcija izstrādāta krimināltiesību doktrīnā, to skaidrojot kā objektīvo saikni starp prettiesisko darbību vai bezdarbību un to radītajām laika ziņā sekojošajām

ārpus noziedzīga nodarījuma sastāva pazīmēm, piemēram, nošķeltā noziedzīga nodarījuma sastāvā, kad, lemjot jautājumu par soda noteikšanu, izvērtējams radītais kaitējums (Krimināllikuma 46. panta otrā daļa).

3 Sk., piem., Krastinš̌ U. Noziedzīga nodarījuma sastāvs un nodarījuma kvalifikācija. Teorētiskie aspekti. Riga: Tiesu namu aǵentūra, 2014, 103. lpp.; Leja M. KRIMINĀLTIESĪBU AKTUĀLIE JAUTĀJUMI UN TO RISINĀJUMI LATVIJĀ, AUSTRIJĀ, ŠVEICĒ, VĀCIJĀ. Noziedzīga nodarījuma uzbūve; cēloṇsakarība; vaina; krimināltiesỉbu normu interpretācija un spēks laikā. I daļa. Rỉga: Tiesu namu aǵentūra, 2019.

4 Sk., piem., Latvijas Republikas Augstākās tiesas Krimināllietu departamenta 2017. gada 6. janvāra lēmums lietā SKK-4/2017.

5 Mincs P. Krimināltiesību kurss. Vispārējā daḷa. Ar U. Krastiņa komentāriem. Rīga: Tiesu namu aǵentūra, 2005, 126. lpp.

6 Sk., piem., Torgāns K. Vairāki zaudējumus (kaitējumu) izraisoši cēloṇi. Jurista Vārds, 2007, Nr. 28. Pieejams: http://www.juristavards.lv [aplūkots 2019. gada 9. maijā]; Kārkliņš J. Vainas, prettiesiskas rīcības un atbildības ideja privāttiesībās. Latvijas Universitātes Žurnāls: Juridiskā zinātne. Nr. 8, 2015; Strazdiṇš G̣. Ieskats cēloniskā sakara vērtēěanas pamatos. Jurista Vārds, 2017, Nr. 19, 18.-25. lpp.

7 Mantrovs V. Cēloniskā sakara izpratnes jautājumi civiltiesību kontekstā. Jurista Vārds, 2016, Nr. 13, 15.-19. lpp.

8 Piem., Latvijas Kriminālkodekss un komentāri pie atsevišķiem Latvijas Kriminālkodeksa pantiem (Dr. iur. A. Niedre). Rīga: Tiesiskās informācijas centrs, 1997.

9 Krimināllikums: LV likums. Latvijas Vēstnesis, 1998. 8. jūlijs, Nr. 199/200.

10 Cēloṇsakarības definējums krimināllikumos ir iestrādāts tikai dažās ārvalstīs, piemēram, Gruzijas kriminālkodeksā (Criminal Code of Georgia. Pieejams: www.legislationline.otg/documents/section/ criminal-codes [aplūkots 2019. gada 9. maijā]).

11 Atzīmējams, ka dažǎdo terminu lietošana nav saistāma ar atš̌kirīgu cēloṇsakarības līmeņu apzīmēšanu, bet drīzāk ar valodas labskanīgumu - sk. plašāk Leja M., 491.- 492. lpp.; Vīnkalna E. Cēloṇsakarība Krimināllikumā un tās nozīme noziedzịgu nodarījumu kvalifikācijā. Tiesību efektivitāte postmodernā sabiedrībā. Latvijas Universitātes 73. zinātniskās konferences rakstu krājums. Rīga: LU Akadēmiskais apgāds, 2015, 204.-211. lpp. 
kaitīgajām sekām, kurā darbība vai bezdarbība sagatavo un nosaka seku iestāšanās iespēju un kurā darbība vai bezdarbība ir galvenais noteicošais faktors, kas neizbēgami radījis kaitīgās sekas. ${ }^{12}$ Atzīmējams, ka Latvijas krimināltiesībās pamatā pausta vienota izpratne, neapšaubot, ka cēlon,sakarība ir objektīvā saikne starp nodarỉjumu un kaitīgajām sekām. ${ }^{13}$

Jānorāda, ka cēloṇsakarības problemātika aktualizēta dažādos laika periodos, piemēram, 20. gadsimta 50. gadu vidū atzīts, ka krimināltiesībās nav izstrādāts vienots viedoklis par kritēriju, pēc kura jānošķir nodarījumi, ar kuriem nodarìtas sekas un kas ir pamats atbildībai, no nodarījumiem, kas, kaut arī ir saistīi ar iestājušos kaitīgo rezultātu, tomēr nav pamats atbildỉbai. ${ }^{14}$ Cenšoties rast precizu cēlonsakarības raksturojumu un vienveidību tās noteikšanā, izstrādātas cēloṇsakarības teorijas, ${ }^{15}$ kuru nostādnes analizētas arī Latvijas krimināltiesībās. Rakstā plašāk akcentētas tikai konkrētas teorijas, ņemot vērā to nozīmīgumu cēlonssakarības izpratnes veidošanā krimināltiesībās. ${ }^{16}$

Krimināltiesībās par noteicošo un izplatītāko cēloṇsakarības izpratnes veidošanā tiek uzskatīta ${ }^{17}$ ekvivalences jeb nosacījumu teorija (saukta arī condicio sine qua non jeb ekvivalences teorija; ${ }^{18}$ priekšnosacijumu ekvivalences teorija), kas izstrādāta 19. gadsimta 60. gados. Pēc ekvivalences jeb nosacijumu teorijas, katrs nosacijums, bez kura kaitīgās sekas neiestātos, uzskatāms par šo kaitīgo seku cēloni. Teorijas izpratnē visi cēloṇi (nosacijumi), kas radījuši sekas, ir līdzvērtīgi jeb ekvivalenti. Ekvivalences

12 Sk., piem., Krastiņš U., Liholaja V. Krimināllikuma komentāri. Pirmā dạ̧a (I-VIII ${ }^{2}$ nodaļa). Otrais papildinātais izdevums. Rìga: Tiesu namu aǵentūra, 2018, 64. lpp.

13 Piemēram, Amerikas Savienoto Valstu Paraugkriminālkodeksa 2.03. pantā ietverta ne tikai cēloṇsakarība kā objektīva kategorija, bet arī cēloṇsakarība kā subjektīva kategorija (cēloṇsakarība starp personas nodomiem (no vienas puses) un rīcību un sekām (no otras puses) - sk. Model Penal Code. Pieejams: www.icla.up.ac.za [aplūkots 2019. gada 9. maijā]; Beḷkka A. Cēloṇsakarība Latvijas un ASV krimināltiesībās. Referāta tēzes. LU 68. zinātniskā konference. 2010. gada 9. februāris.

14 Причинная связь. Юридический словарь. П. И. Кудрявчев (главн. реА.). ИзА. 2-е. Том 2. Москва: Государственноя издательство юридической митературы, 1956, с. 256.

15 Cēloṇsakarības teoriju nostādnēs konstatējama arī atškirīiga cēlon̦sakarîbas izpratne no materiālisma un ideālisma pozīcijām. Materiālismā cēlonssakarība ir objektīva saikne, kura eksistē ārpus cilvēka apziņas. No ideālistiskā pasaules skatījuma cēloṇsakarība ir subjektīva kategorija, kura eksistē tikai subjekta apziņā (subjektīvais ideālisms), vai arī objektīva kategorija, kura radusies objektīvi eksistējošajā saprātā (objektīvais ideālisms) - sk., piem., Пиотковский A. А. Учение о преступкении. Москва: Государственное издательство юридической митературы, 1961, с. 183.

16 Rakstā norādīto teoriju uzskaitījums nav izsmeḷošs, piemēram, izstrādāta arī cēloṇa un nosacijuma teorija (skaidrojot cēloṇa un nosacijuma būtību, tiek akcentēts, ka cēlonis ietver nepieciešamo nosacijumu seku radīšanai, bet ne otrādi - ne katrs nepieciešamais nosacijums ir seku cēlonis; nepieciešamās un nejaušăs cêloṇsakarības teorija; izslēdzošās cēlonības teorija; vainojamās cēlonības teorija. u. c. (sk. Малинин В. Б. Причинная связь в уголовном праве. Санкт-Петербург: Юридический центр Пресс. 2000, с. 105-126).

17 Haft F. Strafrecht Allgemeiner Teil. Eine Einführung für Anfangssemester. München: C. H. Beck'sche Verlagsbuchhandlung, 1998, S. 62. Piemēram, Vācijā un Austrijā ekvivalences jeb nosacijumu teorija ir ietekmīgākā - sk. Leja M. Neuzmanīga līdznodarī̌ana krimināltiesībās. Jurista Vārds. 2011. 30. augusts, Nr. 35, 12. lpp.

18 Piemēram, Rietumu krimināltiesību teorijā cēloṇsakarību pieṇemts apzīmēt ar testu sine qua non ja nebūtu (jeb priekšnoteikums, bez kura nē, teorijas formula latīnu valodā), kas nozīmē, ka X ir Y rezultāts tikai tad, ja X ir bijis pirms un bez X nevarētu iestāties Y (sk. Ķinis U. Noziedzīgi nodarījumi pret informācijas sistēmu drošīu (kibernoziegumi). Promocijas darbs. Latvijas Universitāte, 2005, 120. lpp.). 
jeb nosacijjumu teorija atspogulo cēloṇsakarības objektīvo raksturu starp darbïbu vai bezdarbību un tās izraisìtajām kaitīgajām sekām, kā arī tās pamatā ir filozofijā pieṇemtā cēloṇsakarības izpratne. Vienlaikus teorija tiek kritizēta, ka cēlonssakarība tādējādi var tikt izvērsta līdz bezgalībai, nepamatoti paplašinot kriminālatbildỉbas robežas. ${ }^{19}$ Tomēr iepriekš minētais viedoklis nav atbalstāms, ņemot vērā, ka kriminālatbildības pamats ir noziedzīga nodarījuma sastāvs, kas bez cēlon,sakarības ietver arī citas pazīmes; to skaitā vainu nodoma vai neuzmanības formā. Teorijas nostādnu sakarā pamatoti vērsta uzmanība uz konkrēta cēloṇsakarības veida - alternatīvās cēloṇsakarības (jeb dubultās cēloṇsakarības; kad vismaz divi dažādi cēloṇi rada vienas un tās pašas sekas) - analizēšanu. Alternatīvās cēloṇsakarības pastāvēǎanas gadījumā teorijas konsekventa piemērošana var būt problemātiska. Piemērojot ekvivalences teoriju, neatkarīgi no jebkuras no vismaz divu personu nodarījumiem būtu jākonstatē, ka kaitīgās sekas (piemēram, cietušā nāve) iestātos. Šajā gadỉjumā teorijas nostādnes īpaši izvērtējamas, atzīstot, ka cēlon,sakarība ir konstatējama starp katras personas nodarījumu un kaitīgajām sekām. ${ }^{20}$

Cēlonssakarības pētijumos visai plaši analizēta arī adekvātuma teorija (adekvātā "tipiskā" nodarī̌anas teorija), kas izstrādāta 19. gadsimta beigās ${ }^{21}$ un ỉpašu izplatību guvusi vācu tiesību teorijā. ${ }^{22}$ Adekvātuma teorija pat atzīta par pretstatu ekvivalences jeb nosacijumu teorijai, ${ }^{23}$ nepiel̦aujot cēloņsakarïbas bezgalīgumu, kas var būt raksturīgs ekvivalences teorijai, kā arī cēloṇsakarību vērtējot kā eksistējošu cilvēka apziņā. Adekvātā teorija balstās uz atzinuu, ka, izvērtējot tikai konkrēto gadījumu, nav iespējams izdarīt secinājumus par cēloṇsakarības attīstību. Tikai analizējot vairākus gadījumus, tos attiecīgi sagrupējot pēc to tipiskajām pazīmēm, iespējams secināt, vai attiecīgais nodarījums spēj radīt konkrētās sekas. Savukārt nodarijjumu, kas nebūs tipisks jeb adekvāts, nevar uzskatīt par seku cēloni. Jāatzīst, ka teorija atstāj bez ievērības netipiskus, neparastus nosacijumus, jo par radìto seku cēloni tiek atzìts tikai tāds nodarījums, kas vienmēr noteiktos apstākḷos var radīt noteiktas sekas - piemēram, šāviens galvā izraisa, turpretim viegls sitiens pa galvu - neizraisa nāvi. ${ }^{24} \mathrm{Kā}$ zināms, būtiska nozīme ir cēloṇsakarības un vainas, kā arī motĩva un mērḳa izvērtējuma kopsakaram, piemēram, vai persona ir zinājusi par kādu galvas traumu un apzināti uzsitusi tieši tur, paredzot

19 Sk., piem., Козмов А. П. Понятие преступления. Санкт-Петербург: Юридический центр Пресс, 2004, с. 315; Церетели Т. В. Причинная связь в уголовном праве. Москва: Государственное изАательство Юридической Аитературы, 1963, с. 129-151.

20 Leja M., 2011. 30. augusts, Nr. 35, 12. lpp.

${ }^{21}$ Sk., piem., Mincs P., 130. lpp.

22 Церетели Т. В. Причинная связь в уголовном праве. Москва: Государственное изАательство Юридической митературы, 1963, с. 97; Wessels J., Beulke W. Strafrecht Allgemeiner Teil. Heidelberg: C. F. Müller Verlag, 2000, S. 55.

23 Mincs P., 130. lpp.; Mincs P. Krimināltiesību kurss. Vispārējā daḷa. Rīga: autora izdevums, 1934, 110.-111.lpp.

24 Atkarībā no tā, kā pieredze ir jānem vērā, analizējot cēlonssakarību, adekvāto teoriju pamatā iedala divos virzienos: subjektīvajā un objektīvajā. Subjektīvajā virzienā cēlonssakarības jautājuma izlemšanā jāṇem vērā visi tipiskie nosacījumi, kas bija zināmi vai vismaz paredzami personai nodarijuma laikā. Šajā gadījumā cēloṇsakarība tiek identificēta ar vainu. Savukārt ar adekvātās teorijas objektîvo virzienu tipiskuma novērtējumu var sniegt tiesa, jebkurš saprātīgs cilvēks, erudīts jurists - sk. Соктоев 3. Б. Причинность в уголовном праве: о преломмении фимософской категории. Российский ежегоАник уголовного права. 2007. № 2. Санкт-Петербург: ООО Университетский изАательский консорциум «Юридическая книга», 2008, с. 305-324; Leja M., 532.-534. lpp. 
nāves sekas, un, lai gan nodarījuma rezultātā iestājušās sekas nav tipiskas, cēloṇsakarība pastāv. Adekvātās teorijas nostādnes pamatoti tiek kritizētas, norādot, ka cēlon, nsakarība ir parādỉbu objektīvā saikne un nav atkarīga no konkrētu personu domām, tādējādi cēlon, sakarībai zaudējot patstāvīgas noziedzīga nodarījuma sastāva pazīmes nozìmi. ${ }^{25}$

Galvenā cēloṇa teorijā no visiem konkrētā notikuma nosacījumiem mēgeināts izdalìt tādu cēloni, kuram piemīt noteicošā (izšķirošā) nozīme konkrēto seku radīšanā. Pēc šās teorijas, par iestājušos seku cēloni var uzskatīt tikai galveno darbību (bezdarbību), kas atstājusi vislielāko iespaidu uz kaitīgajām sekām. ${ }^{26}$ Šìs teorijas trūkumi un kḷūdainie aspekti tika atzīti jau 19. gadsimta sākumā, ${ }^{27}$ pamatoti akcentējot, ka galvenā cēloṇa teorija piẹ̦auj nepamatotu izvairī̌sanos no kriminālatbildỉbas un soda, kā tas var būt gadījumos, kad noziedzīgu nodarījumu izdara vismaz divas personas - ja viena persona cietušajam situsi mazāk nekā otra, pēc galvenā cēloṇa teorijas, tā nebūtu saucama pie kriminālatbildības. ${ }^{28}$ Jāatzīmē, ka Latvijas tiesu praksē šāda nostādne tiek noliegta, ${ }^{29}$ atzīstot, ka gadỉjumos, kad vairākas personas noziedzīgu nodarījumu izdara kopīgi, katras konkrētās personas darbības no cēloṇsakarības konstatēšanas viedokḷa ir vērtējamas kā kopīgs cēlonis, kad katras personas atsevišķais nodarījums kḷūst par dalu no cēloṇa, kas izraisījis noteiktas sekas.

Jānorāda, ka krimināltiesību doktrīnā nostiprinātās iepriekš minētās cēloṇsakarības definīcijas viena no prasībām ir: darbību vai bezdarbību par seku cēloni ir pamats atzìt tikai tad, ja iestājušās sekas ir bijušas neizbēgamas. Skaidrojot minēto prasību, teikts, ka par neizbēgamām sekas var uzskatīt tad, ja tās noteiktā vietā, laikā un apstākḷos nenovēršami izraisījusi noteikta darbība vai bezdarbības akts, tātad cēlon,sakarība ir bijusi minēto apstākḷu nepieciešamība. ${ }^{30}$ Krimināltiesībās tiek arī norādīts, ka seku neizbēgamība nevarētu tikt atzìta par obligātu cēlon,sakarības pazīmi, jo tad cēloṇsakarība būtu atzīstama tikai izṇēmuma gadijjumos. ${ }^{31}$ Autores ieskatā, "neizbēgams" un "nepieciešams” kā jēdzieni būtu norobežojami, un, lai izvairītos no iespējami

25 Sk. Козмов А. П. Понятие преступмения. Санкт-Петербург: Юридический центр Пресс, 2004, c. 316; Leja M., 495. lpp.

26 Малинин В. Б. Причинная связь в уголовном праве. Санкт-Петербург: Юридичесий центр Пресс, 2000, с. 98.

27 Коржанский Н. И., Павлов В. Г., Рарог Ф. И. Энциклопедия уголовного права. Т. 4. Состав преступления. Санкт- Петербург: изА. проф. Малинина, 2005, с. 344.

28 Малинин В. Б., Парфенов А. Ф. Объективная сторона преступления. Санкт-Петербург: ИзАательство Юридического института, 2004, с. 99.

29 Sk., piem. Tukuma rajona tiesas 2016. gada 20. maija spriedums lietā Nr. 11390041614, lietas arhîva Nr. K37-0037-16/2; Vidzemes apgabaltiesas 2013. gada 26. novembra spriedums lietā Nr. 11300021411, lietas arhīva Nr. KA05-0111-13/13; Latvijas Republikas Augstākās tiesas Krimināllietu departamenta 2017. gada 6. janvāra lēmums lietā Nr. SKK-4/2017, 4., 5. lp.; Latvijas Republikas Augstākā tiesa. Noziedzīgu nodarījumu par smagiem miesas bojājumiem kvalifikācijas jautājumi tiesu praksē (Krimināllikuma 125., 127.-129., 131., 132. pants) un to kopība ar citiem noziedzīgiem nodarījumiem. Pēc Augstākās tiesas pasūtijuma apkopojumu organizējusi Latvijas Universitāte, sagatavojusi Dr. iur. prof. V. Liholaja. Rīga, 2017, 10. lpp. Pieejams: www.at.lv. [aplūkots 2019. gada 12. maijā]

30 Krastiņš U., Liholaja V., Niedre A. Krimināltiesības. Vispārīgā daļa. Trešais papildinātais izdevums. U. Krastiņš (zin. red.). Rīga: Tiesu namu aǵentūra, 2008, 132. lpp.

31 Sk., piem., Leja M., 482. lpp; Козмов А. П. Понятие преступления. Санкт-Петербург: Юридический центр Пресс, 2004, с. 339-342. 
dažādā "neizbēgams" traktējuma, tādā veidā pat novedot pie cēloṇsakarības izpratnes sašaurināšanas, norādi uz neizbēgamību nebūtu nepieciešams ietvert cēloṇsakarības definējumā.

Pēc nepastarpinātā (tuvākā) cēloṇa teorijas, par cēloni var atzìt tikai pēdējo, nepastarpināto un sekām tuvāko nodarījumu. Tā kā attiecīgā teorija krimināltiesisku nozīmi piešķir tikai nodarījumam tuvākajām kaitīgajām sekām, to dēvē arī par tuvākā cēloṇa koncepciju. ${ }^{32}$ Ar teoriju tiek saprasts, ka iestājies kaitējums nevar būt tik attālināts vai nejaušs (vai tik atkarīgs no cita uzvedības), lai būtu nozīmīgs jautājuma izlemšanai par atbildības iestāšanos. Jāsecina, ka nepastarpinātā (tuvākā) cēloṇa teorija nepamatoti ierobežo cēlon,sakarības noteikšanas robežas, jo, apzīmējot cēlon,sakarības pastāvēšanas nepieciešamību, uzsvars tiek likts uz tiešas cēloṇsakarības nepieciešamību. Lai gan praksē visai bieži cēlon,sakarība tiek apzīmēta "tieša cēlon,sakarība",,33 nevarētu atzìt, ka ar to domāta tikai tāda cēlon,sakarība, kad nodarījums vērtējams kā tiešs cēlonis, kas radījis kaitīgās sekas. Attiecīgo norādi varētu skaidrot ar to, ka jēdziena "tieša” izpratne ne vienmēr tiek traktēta nepārprotami. Pastāv viedoklis, ka cēloṇsakarība starp noziedzīgo darbību vai bezdarbību un tās izraisītām kaitīgajām sekām ir objektīva un tai piemìt krimināli tiesiska nozīme, ja tā ir tieša (nepieciešama), bet ne netieša (nejauša). ${ }^{34}$ Tomēr, domājams, ka praksē visai bieži lietotais apzīmējums "tieša cēloṇsakarība”, "tiešs cēlonis” drīzāk ir neprecīzs, nepārdomāts termins. ${ }^{35}$ Tā, piemēram, norāde uz "tiešu cēloni” ietverta Zemgales rajona tiesas spriedumā, ar kuru [pers. B] atzīta par vainīgu saskaṇā ar Krimināllikuma 146. panta otro dalıu (būdams uzņēmējsabiedrības vadītājs, kas atbildīgs par šo noteikumu ievērošanu, [pers. B] pārkāpa darba aizsardzības reglamentējošo normatīvo aktu prasības, kā rezultātā iestājās cilvēka nāve). Tiesa spriedumā pamatoti norāda, ka tā konstatē "cēloṇsakarību starp [pers. B] rīcību darba aizsardzību reglamentējošo normatīvo aktu prasību pārkāpšanā un sekām - darbinieka [pers. D] nāvi. [Pers. D], veicot tiešos darba pienākumus, tīrot suliṇu tvertni, iekrita tajā, kā rezultātā no mehāniskās asfiksijas iestājās viṇa nāve. [Pers. B] bezdarbība, nenodrošinot [pers. D] darba aizsardzības ievadapmācību un sākotnējo instruktāžu darba vietā, nenodrošinot un neveicot pilnvērtīgu uzraudzību un kontroli darba veikšanas laikā, piel̦aujot, ka [pers. D] veic darbu, atrodoties alkohola reibuma stāvoklī, kā arī nenodrošinot darba vides riska novērtēšanu sulinuu tvertnes tīrīšanai, neiepazīstinot [pers. D] ar šādu darba vietas darba vides riska novērtējumu, bija tiešais cēlonis nelaimes gadījumam darbā." ${ }^{36}$

Vienlaikus jāakcentē, ka tiek izteikta arī norāde, ka cēlon,sakarībai ir jābūt tiešai. Ar Rīgas pilsētas Vidzemes priekšpilsētas tiesas spriedumu atzīts, ka [pers. H] nolaidīgi pildījis ārstniecības personas profesionālo pienākumu, kas vainīgā neuzmanības dēḷ bija par iemeslu cietušā nāvei pēc Krimināllikuma 138. panta otrās daļas. Tiesa atzina,

32 Piem., Соктоев 3. Б. Причинность в уголовном праве: о преломлении философской категории. Российский ежегоАник уголовного права. 2007. №2. ООО Университетский изАательский консорциум «Юридическая книга», 2008, с. 305-324.

33 Sk., piem., Latvijas tiesas. Nolēmumi. Pieejams: https://manas tiesas.lv

34 Шарапов Р. А. Физическое насилие в уголовном праве. Санкт-Петербург: Юридический центр Пресc, 2001, с. 138.

35 Leja M., 495.-496. lpp.

36 Zemgales rajona tiesas 2018. gada 29. augusta spriedums lietā Nr. K73-0976-18/45. 
ka [pers. H] piẹ̦āva neuzmanību, neattaisnotu vilcināšanos, nolaidīgi pildīja savus ārsta pienākumus un nelēma jautājumu par nekavējošu neatliekamu epidurālās hematomas operatīvu evakuāciju, pastāvot reālai iespējai veikt kirurgísku iejaukšanos, nolūkā glābt [pers. I] dzīvību, neievērojot Ārstniecības likuma 37. panta pirmās dalasas 1., 2. punktu, kas [pers. H] neuzmanības dēl bija par iemeslu [pers. I] nāvei. [Pers. I] uz slimnīcu nogādāts pēc tam, kad viñš naktī bija aplaupîts un piekauts, nodarot smagus dzīvībai bīstamus miesas bojājumus. ${ }^{37}$ Jāatzīmē, ka nodarījuma kvalifikāciju par pareizu atzina arī Rīgas Apgabaltiesas Krimināllietu tiesas kolēǵija, vēršot uzmanību cēloṇsakarības konstatěšanas jautājumam starp [pers. $\mathrm{H}$ ] nodarījumu un [pers. I] nāves iestāšanos. Apsūdzībā norādìts, ka vēlíni organizētajiem pasākumiem operācijas uzsākšanai un savlaicīgai neizdarīšanai ir zināma cēloniska sakarība ar [pers. I] nāves iestāšanos no trulas galvas traumas. Pēc aizstāvja domām, norāde uz šãdu cēloṇsakarības pastāvēšanu neatbilst tiesību teorijā paustajam, no kā izrietot, ka cēloṇsakarībai ir jābūt tiešai, konkrētai un precizai. Ekspertu atzinumā Nr. 292 secināts, ka starp iegūto traumu un [pers. I ] nāves iestāšanos ir cēlonisks sakars, eksperts [pers. B] norādījis, ka [pers. H] darbība nevarēja novest pie nāves tiešã ceḷā un jāuzskata, ka galvenais nāves cēlonis ir miesas bojājumi. Apelācijas instances tiesa pamatoti norādīja, ka nevar pievienoties apsūdzētā un viña aizstāvja argumentiem par to, ka [pers. $\mathrm{H}$ ] būtu attaisnojams, jo miesas bojājumi [pers. I] nodarīti laupīšanas uzbrukumā, uzsverot, ka Krimināllikuma 138. panta dispozīcija prezumē noziedzīgā nodarījuma objektīvās puses izpaušanos ārstniecības personas profesionālajā darbībāārstniecības procesā, un ir pašsaprotami, ka ārstniecỉbas persona savu profesionālo pienākumu veic pret personu, kurai ir veselības traucējumi, šajā gadījumā, noziedzīga nodarījuma dēl [pers. I] radusies galvas trauma. ${ }^{38}$ Arī Augstākā tiesa pamatoti norādīja, ka abu zemāko instanču tiesu atzinumi par to, ka vēlīni organizētajiem pasākumiem operācijas uzsākšanai un tās neizdarišsanai laikā bija cēloniska sakarība ar cietušā nāves iestāšanos, uzsverot, ka zemāko instanču tiesas nav konstatējušas nejaušỉbu cēloṇsakarībā. ${ }^{39}$ No iepriekš minētā secināms, ka cēloṇsakarība kā saikne starp nodarījumu un kaitīgajām sekām nav atzīstama tikai kā tieša saikne, kā arī, lai starp personas nodarījumu un kaitīgajām sekām konstatētu cēlonssakarïbu, nodarijumam ne vienmēr jābūt tikai galvenajam cēlonim.

\section{Kopsavilkums}

1. Cēloṇsakarība kā materiālo noziedzīgu nodarỉjumu sastāvu objektīvās puses pazīme izriet no krimināltiesiskās normas uzbūves, tās konstatēšanas nepieciešamību nosakot ar noziedzīga nodarījuma sastāvā ietvertajām kaitīgajām sekām.

37 Rīgas pilsētas Vidzemes priekšpilsētas 2016. gada 20. aprịḷa spriedums krimināllietā Nr. 11094066909.

38 Riggas apgabaltiesas Krimināllietu tiesas kolēgijas 2017. gada 21. jūnija spriedums lietā Nr. 11094066909, KA04-0109-17/20.

39 Latvijas Republikas Augstākās tiesas Krimināllietu departamenta 2017. gada 22. decembra lēmums lietā Nr. SKK-707/2017. 
Cēlon,sakarības apzīmēšanai lietoti arī termini “izraisīt”, "radīts”, "nodarīts”, "bijis par iemeslu”.

2. Cenšoties rast precīzu cēloṇsakarības raksturojumu un vienveidību tās noteikšanā, izstrādātas cēloṇsakarības teorijas. Krimināltiesībās par noteicošo un izplatītāko tiek uzskatīta ekvivalences jeb nosacījumu teorija, jo tā atspoguḷo cēloṇsakarības objektīvo raksturu starp darbību vai bezdarbību un tās izraisìtajām kaitīgajām sekām. Teorijas nostādnes atbalstu guvušas arī Latvijas krimināltiesībās.

3. Lai gan praksē visai bieži cēlon,sakarība tiek apzīmēta “tieša cēlon,sakarība”, nevarētu uzskatīt, ka ar to tikai saprotami gadijjumi, kad nodarījums vērtējams kā tiešs cēlonis, kas radījis kaitīgās sekas. Iespējams, ar apzīmējumu "tieša cēloṇsakarība” saprotama cēloṇsakarību raksturojošā lieluma - nepieciešamības - pastāvēšana (krimināltiesībās izteikts arī viedoklis, ka cēloṇsakarība starp noziedzīgo darbību (bezdarbību) un tās izraisītām kaitīgajām sekām ir objektīva un tai piemīt krimināli tiesiska nozīme, ja tā ir tieša (nepieciešama), bet ne netieša (nejauša)). Vienlaikus, jādomā, ka praksē lietotos apzīmējumus "tieša cēloṇsakarība”, "tiešs cēlonis” zināmos gadījumos varētu vērtēt kā neprecīzus terminus.

4. Autores ieskatā, "neizbēgams” un "nepieciešams" kā jēdzieni būtu norobežojami, un, lai izvairītos no iespējami dažādā "neizbēgams” traktējuma, kas var radìt cēloṇsakarības izpratnes sašaurināšanos, norādi uz neizbēgamību nebūtu nepieciešams ietvert cēlon,sakarības definējumā.

\section{BIBLIOGRĀFIJA}

\section{Literatūra}

1. Beḷska A. Cēloṇsakarība Latvijas un ASV krimināltiesībās. Referāta tēzes. LU konference. 2010. gada 9. februāris.

2. Haft F. Strafrecht Allgemeiner Teil. Eine Einführung für Anfangssemester. München: C. H. Beck'sche Verlagsbuchhandlung, 1998.

3. Kārkliņš J. Vainas, prettiesiskas rīcības un atbildības ideja privāttiesībās. Latvijas Universitātes Žurnāls: Juridiskā zinātne. Nr. 8, 2015, 154.-175. lpp.

4. Krastiņš U., Liholaja V. Krimināllikuma komentāri. Pirmā daļa (I-VIII ${ }^{2}$ nodaļa). Otrais papildinātais izdevums. Rìga: Tiesu namu aǵentūra, 2018.

5. Krastiņ̌̌ U., Liholaja V., Niedre A. Krimināltiesības. Vispārīgā daļa. Trešais papildinātais izdevums. U. Krastinšs (zin. red.). Rīga: Tiesu namu aǵentūra, 2008.

6. Krastinš̌ U. Noziedzīga nodarījuma sastāvs un nodarījuma kvalifikācija. Teorētiskie aspekti. Rīga: Tiesu namu aǵentūra, 2014.

7. Ķinis U. Noziedzīgi nodarījumi pret informācijas sistēmu drošību (kibernoziegumi). Promocijas darbs. Latvijas Universitāte, 2005.

8. Langsted L. B., Greve V. Criminal Law. Denmark. 2. edition. Copenhagen: DJOF Publishing, 2004.

9. Leja M. KRIMINĀLTIESİBU AKTUĀLIE JAUTĀJUMI UN TO RISINĀJUMI LATVIJĀ, AUSTRIJĀ, ŠVEICĒ, VĀCIJĀ. Noziedzịga nodarījuma uzbūve; cēloṇsakarība; vaina; krimināltiesību normu interpretācija un spēks laikā. I daḷa. Rīga: Tiesu namu aǵentūra, 2019. 
10. Leja M. Neuzmanīga līdznodarīšana krimināltiesībās. Jurista Vārds. 2011. 30. augusts, Nr. 35, 12.lpp.

11. Liholaja V. Noziedzīgu nodarījumu kvalifikācija: Likums. Teorija. Prakse. Otrais papildinātais izdevums. Rìga: Tiesu nama aǵentūra, 2007.

12. Mantrovs V. Cēloniskā sakara izpratnes jautājumi civiltiesību kontekstā. Jurista Vārds, 2016, Nr. 13.

13. Mincs P. Krimināltiesību kurss. Vispārējā daļa. Ar U. Krastiņa komentāriem. Rīga: Tiesu namu ağentūra, 2005.

14. Mincs P. Krimināltiesību kurss. Vispārējā daḷa. Rīga: autora izdevums, 1934.

15. Strazdiņš Ģ. Ieskats cēloniskā sakara vērtēšanas pamatos. Jurista Vārds, 2017, Nr. 19.

16. Torgāns K. Vairāki zaudējumus (kaitējumu) izraisoši cēloṇi. Jurista Vārds, 2007, Nr. 28. Pieejams: http://www.juristavards.lv.

17. Vīnkalna E. Cēloņsakarība Krimināllikumā un tās nozīme noziedzīgu nodarïjumu kvalifikācijā. Tiesību efektivitāte postmodernā sabiedrībā. Latvijas Universitātes 73. zinātniskās konferences rakstu krājums. Rīga: LU Akadēmiskais apgāds, 2015, 204.-211.lpp.

18. Wessels J., Beulke W. Strafrecht Allgemeiner Teil. Heidelberg: C. F. Müller Verlag, 2000.

19. Козаченко И. Я., Курченко В. Н., ЗАоченко Я. М. Проблемы причины и причинной связи в институтах Общей и Особенной частей отечественного уголовного права: вопросы теории оперативно - следственной и судебной практики. Санкт-Петербург: Юридический центр Пресс, 2003.

20. Козмов А. П. Понятие преступмения. Санкт-Петербург: Юридический центр Пресс, 2004.

21. Коржанский Н. И., Павлов В. Г., Рарог Ф. И. Энциклопедия уголовного права. Т. 4. Состав преступления. Санкт- Петербург: изА. проф. Малинина, 2005.

22. Малинин В. Б., Парфенов А. Ф. Объективная сторона преступления. Санкт-Петербург: ИзАательство Юридического института, 2004.

23. Малинин В. Б. Причинная связь в уголовном праве. Санкт-Петербург: Юридический центр Пресс, 2000.

24. Пиотковский А. А. Учение о преступкении. Москва.: Государственное изАательство юриАической китературы, 1961.

25. Соктоев 3. Б. Причинность в уголовном праве: о преломлении философской категории. Российский ежегодник уголовного права. 2007. № 2. Санкт-Петербург: ООО Университетский издательский консорциум «Юридическая книга», 2008.

26. Церетели Т. В. Причинная связь в уголовном праве. Москва: Государственное издательство Юридической митературы, 1963.

27. Шарапов Р. А. Физическое насилие в уголовном праве. Санкт-Петербург: Юридический центр Пресс, 2001.

28. Юридический словарь. П. И. Кудрявчев (главн. реА.). ИзА. 2-е. Том 2. Москва: Государственная изАательство юридической митературы, 1956.

\section{Normativie akti}

29. Krimināllikums: LV likums. Latvijas Vēstnesis, 1998. 8. jūlijs, Nr. 199/200.

30. Latvijas Kriminālkodekss un komentāri pie atsevišķiem Latvijas Kriminālkodeksa pantiem (Dr. jur. A. Niedre). Rīga: Tiesiskās informācijas centrs, 1997.

31. Criminal Code of Georgia. Pieejams: www.legislationline.otg/documents/section/criminal-codes.

32. Model Penal Code. Pieejams: www.icla.up.ac.za. 


\section{Juridiskā prakse}

33. Latvijas Republikas Augstākās tiesas Krimināllietu departamenta 2017. gada 6. janvāra lēmums lietā Nr. SKK-4/2017.

34. Latvijas Republikas Augstākās tiesas Krimināllietu departamenta 2017. gada 22. decembra lēmums lietā Nr. SKK-707/2017.

35. Latvijas Republikas Augstākā tiesa. Noziedzīgu nodarījumu par smagiem miesas bojājumiem kvalifikācijas jautājumi tiesu praksē (Krimināllikuma 125., 127.-129., 131., 132. pants) un to kopỉba ar citiem noziedzīgiem nodarījumiem. Pēc Augstākās tiesas pasūtỉjuma apkopojumu organizēja Latvijas Universitāte, sagatavojusi Dr. iur. prof. V. Liholaja. Rìga, 2017. Pieejams: www.at.lv.

36. Rīgas apgabaltiesas Krimināllietu tiesas kolēgijas 2017. gada 21. jūnija spriedums lietā Nr. 11094066909, KA04-0109-17/20.

37. Vidzemes apgabaltiesas 2013. gada 26. novembra spriedums lietā Nr. 11300021411, lietas arhīva Nr. KA05-0111-13/13.

38. Rīgas pilsētas Vidzemes priekšpilsētas 2016. gada 20. aprīḷa spriedums krimināllietā Nr. 11094066909.

39. Tukuma rajona tiesas 2016. gada 20. maija spriedums lietā Nr. 11390041614, lietas arhīva Nr. K37-0037-16/2.

40. Zemgales rajona tiesas 2018. gada 29. augusta spriedums lietā Nr. K73-0976-18/45. 